\title{
DAMPAK PREHABILITASI PADA PASIEN PRAOPERASI
}

\author{
The impact of Prehabilitation on Pre Operation Patients \\ Rejo $^{1}$, Dewi Arradini ${ }^{2}$, Aquartuti Tri Darmayanti ${ }^{3}$, Aris Widiyanto ${ }^{3}$, Joko Tri \\ Atmojo ${ }^{1}$ \\ ${ }^{1}$ Sekolah Tinggi Ilmu Kesehatan Mamba'ul 'Ulum Surakarta \\ ${ }^{2}$ Sekolah Tinggi Ilmu Kesehatan Mitra Husada Karanganyar \\ ${ }^{3}$ Ikatan Mahasiswa dan Alumni Magister Ilmu Kesehatan Masyarakat, \\ Universitas Sebelas Maret \\ (rejopras6@gmail.com)
}

\begin{abstract}
ABSTRAK
Latar Belakang: Prehabilitasi merupakan pendekatan proaktif yang memungkinkan pasien mengoptimalkan aktivitas fisik praoperasi dan memerangi kemungkinan penurunan fungsional. Namun, bukti efektivitas prehabilitasi masih tidak konsisten.

Tujuan: Tinjauan sistematis ini bertujuan untuk merangkum dan mengkritisi dampak dari prehabilitasi berdasarkan studi randomized controlled trial (RCT).

Metode: Artikel dicari melalui basis data sejak Juli - Agustus 2020 . Pencarian diperoleh dari berbagai basis data seperti: PUBMED, MEDLINE, CINAHL, dan Google Scholar dengan rentang publikasi artikel tahun 2010-2020. Kata kunci yang digunakan adalah "prehabilitation and Randomizzed controlled trial (RCT)" ATAU "impact of prehabilitation and surgery patient", ATAU " prehabilitasi dan RCT dan pasien bedah". Kriteria inklusi: artikel yang terpublikasi menggunakan bahasa Inggris atau Indonesia. Subyek merupakan pasien yang melakukan operasi dengan pembiusan parsial atau total dan berusia diatas 18 tahun. Tindakan yang diberikan adalah prehabilitasi dengan berbagai teknik. Artikel dengan desain randomizzed controlled trial (RCT).
\end{abstract}

Hasil: Sebanyak 20 artikel memenuhi syarat kualitatif. Berdasarkan penelitian yang telah terpublikasikan sebanyak 11 artikel menyatakan bahwa prehabilitasi dapat memberikan efek yang positif terhadap pasien pascaoperasi, yang dibuktikan dengan berbagai indikator diantaranya: penurunan risiko komplikasi, peningkatan kapasistas organ vital, serta waktu pemulihan yang lebih cepat. Latihan fisik tetap menjadi bentuk yang paling mudah karena tidak harus direhabilitasi oleh dokter spesialis dan dapat dilakukan kapan saja. Program rehabilitasi yang sukses, tidak hanya berfokus pada fisik melainkan psikologis.

Simpulan: Prehabilitasi cenderung memberi efek positif pada pasien pascaoperasi, meskipun tidak ada penelitian yang mengevaluasi hasil jangka panjang. Tinjauan sistematis ini masih dibatasi oleh heterogenitas studi berkenaan dengan jenis pembedahan, cara rehabilitasi, dan berbagai bias yang sudah dilaporkan sebelumnya sehingga masih ada peluang untuk penelitian terkait standardisasi atau konsensus lebih lanjut terkait prehabilitasi untuk menetapkan pedoman.

Kata kunci: Prehabilitasi, Praoperasi, Tinjauan sistematis 


\begin{abstract}
Background: Prehabilitation is a proactive approach that allows patients to optimize preoperative physical activity and combat possible functional decline. However, the evidence for the effectiveness of prehabilitation is still inconsistent.

The Purpose: This systematic review aims to summarize and critique the impact of prehabilitation based on a randomized controlled trial (RCT).

Method: Articles searched through database from July - August 2020. Searches were obtained from various databases such as: PUBMED, MEDLINE, CINAHL, and Google Scholar with a range of article publications in 2010-2020. The key words used were "prehabilitation and randomized controlled tria (RCT)" OR "impact of prehabilitation and surgery patient", OR "prehabilitation and RCT and surgical patients". Inclusion criteria: Articles published in English or Indonesian. Subjects were patients who underwent surgery with partial or total anesthesia and were over 18 years of age. The action given is prehabilitation with various techniques. Article with a randomizzed controlled trial (RCT) design.

Results: A total of 20 articles met the qualitative requirements. Based on published research, 11 articles state that prehabilitation can have a positive effect on postoperative patients, as evidenced by various indicators including: reduced risk of complications, increased capacity of vital organs, and faster recovery times. Physical exercise remains the easiest form because it does not have to be rehabilitated by a specialist and can be done at any time. A successful rehabilitation program does not only focus on the physical but psychological.

Conclusion: Prehabilitation tends to have a positive effect in postoperative patients, although there are no studies evaluating long-term outcomes. This systematic review is still limited by the heterogeneity of studies with regard to the type of surgery, means of rehabilitation, and various biases that have been previously reported so that there is still room for further standardization or consensus research related to prehabilitation to establish guidelines.
\end{abstract}

Keywords: Prehabilitation, Preoperative, Systematic Review

\title{
PENDAHULUAN
}

Operasi besar elektif dilakukan pada setidaknya 230 juta orang setiap tahun, dan tren ini cenderung meningkat. Peningkatan ini adalah hasil dari pertumbuhan populasi yang menua, perkembangan teknik bedah baru, dan penyediaan layanan bedah dari negara berpenghasilan rendah hingga tinggi yang membaik (Rose et al., 2015; Kamarajah et al., 2020).

Namun demikian, pasien menjalani operasi masih digolongkan sebagai risiko tinggi karena berbagai faktor risiko pascaoperasi yang dapat memperburuk keadaan seperti usia lanjut, komorbiditas, dan obesitas. Faktor-faktor ini tidak hanya terkait dengan hasil pascaoperasi yang merugikan tetapi mungkin pasien akan mengalami komplikasi pascaoperasi. Komplikasi yang berlangsung dalam 30 hari telah dilaporkan menurunkan tingkat kelangsungan hidup jangka panjang. 
Bahkan tanpa adanya komplikasi dilaporkan terjadi penurunan $20 \%$ sampai $40 \%$ fungsi fisik pada pasien (Barberan-Garcia et al., 2018).

Upaya untuk meningkatkan hasil operasi sebagian besar difokuskan pada peningkatan teknik pembedahan, anestesi, dan perawatan di rumah sakit segera setelah operasi. Namun, pendekatan belum cukup maksimal dalam meningkatkan hasil bedah. Paradigma akhirnya bergeser cukup jauh dengan mengupayakan prehabilitasi. Prehabilitasi diartikan sebagai intervensi persiapan yang bertujuan untuk mengurangi komplikasi perioperatif dimana keduanya meningkatkan kapasitas aerobik, melalui pelatihan untuk latihan ketahanan dan aktivitas fisik yang dapat memainkan peran sentral pada tubuh pasien (Older and Levett, 2017; Barberan-Garcia et al., 2018).

Prehabilitasi merupakan pendekatan proaktif yang memungkinkan pasien menjadi partisipan aktif dalam perawatan mereka. Konsep prehabilitasi dianalogikan dengan pelatihan maraton didasarkan pada prinsip yang terstruktur dan latihan berkelanjutan selama beberapa minggu sehingga terjadi peningkatan kardiovaskular, pernapasan, dan pengkondisian otot. Latihan dalam persiapan untuk operasi dikaitkan dengan tingkat komplikasi postoperatif yang lebih rendah dan pemulihan status fungsional lebih awal (Boshier et al., 2018).

Mengoptimalkan aktivitas fisik praoperasi dan memerangi kemungkinan penurunan fungsional merupakan langah yang sangat penting. Studi sebelumnya melaporkan bahwa pasien yang memiliki fungsi praoperasi yang baik juga memiliki fungsi yang lebih baik pascaoperasi. Oleh karena itu, prehabilitasi (prehab) juga bertujuan untuk mempertahankan tingkat fungsionalitas normal dan mencapai pemulihan fungsional yang lebih cepat pascaoperasi (Mayo et al., 2011; Wittink, Engelbert and Takken, 2011).

Namun, bukti efektivitas prehabilitasi tidak konsisten. Studi sebelumnya melaporkan pasien yang telah menjalani cangkok bypass arteri koroner (CABG), prehab dalam bentuk pelatihan otot inspirasi menunjukkan hasil signifikan dalam pengurangan komplikasi paru pasca operasi dan LOS, tetapi tidak pada pasien yang pernah mengalaminya operasi artroplasti lutut (TKA) total atau artroplasti pinggul total (THA) untuk osteoartritis (Valkenet et al., 2011). Satu ulasan menunjukkan prehab tidak meningkatkan status fungsional pasien baik secara obyektif atau subyektif pada pasien setelah TKA atau THA untuk osteoartritis (Oosting et al., 2012).

Meskipun mekanisme tindakannya belum disepakati ketepatannya, tampaknya logis bahwa preconditioning (prehabilitasi) memungkinkan pasien untuk bertahan dengan lebih baik terhadap stres pascaoperasi. Selain itu, status gizi praoperasi yang buruk atau sarcopenia telah dikaitkan dengan peningkatan dalam komplikasi pascaoperasi dan hasil pembedahan yang lebih buruk (Kamarajah, Bundred and Tan, 2019).

Sampai saat ini, bukti tentang dampak prehabilitasi pada pasien yang telah menjalani operasi besar dan pasien yang mengalami komplikasi pascaoperasi masih belum jelas. Tinjauan sistematis ini bertujuan untuk merangkum dan 
mengkritisi dampak dari prehabilitasi berdasarkan literatur randomized controlled trial $(R C T)$ yang tersedia saat ini.

\section{METODE PENELITIAN}

\section{Strategi pencarian}

Artikel dicari melalui basis data sejak Juli - Agustus 2020. Pencarian diperoleh dari berbagai basis data seperti: PUBMED, MEDLINE, CINAHL, dan Google Scholar dengan rentang publikasi artikel antara tahun 2010-2020. Tidak ada upaya dari penulis untuk mencari secara spesifik artikel-artikel tidak terpublikasi. Kata kunci yang digunakan adalah "prehabilitation and Randomizzed controlled trial $(R C T)$ " ATAU "impact of prehabilitation and surgery patient”, ATAU " prehabilitasi dan RCT dan pasien bedah".

\section{Kriteria Inklusi}

Artikel yang terpublikasi menggunakan bahasa Inggris atau Indonesia. Subyek merupakan pasien yang melakukan operasi dengan pembiusan parsial atau total dan berusia diatas 18 tahun. Tindakan yang diberikan adalah prehabilitasi dengan berbagai teknik. Artikel dengan desain randomizzed controlled trial (RCT).

\section{Kriteria Eksklusi}

Artikel yang terpublikasi menggunakan bahasa Cina, Jepang, Spanyol, dan Arab. Subyek merupakan pasien yang melakukan operasi berusia $\geq 18$ tahun. Artikel dengan desain studi kasus, quasi eksperimental, dan kasus kontrol.

\section{Strategi Penilaian kualitas dan sintesis data}

Semua studi yang teridentifikasi dinilai secara independen oleh seluruh penulis untuk relevansi berdasarkan judul dan abstrak. Versi teks lengkap dari semua kemungkinan relevan, ketidaksepakatan diantara penulis diputuskan melalui forum diskusi. Tidak dilakukan kontak dengan seluruh penulis artikel, dikarenakan keseluruhan informasi utama sudah didapatkan dalam artikel terpublikasi.

Data yang telah tersaring disajikan dalam tabel alur sesuai dengan item PRISMA (prefered items of systematic review and meta-analysis) (Liberati et al., 2009). Artikel yang tidak masuk dalam kriteria kualitatif, sebagian besar akan dibahas dalam artikel ini dan dijadikan sumber kepustakaan. 


\section{HASIL DAN PEMBAHASAN}

\section{Hasil}

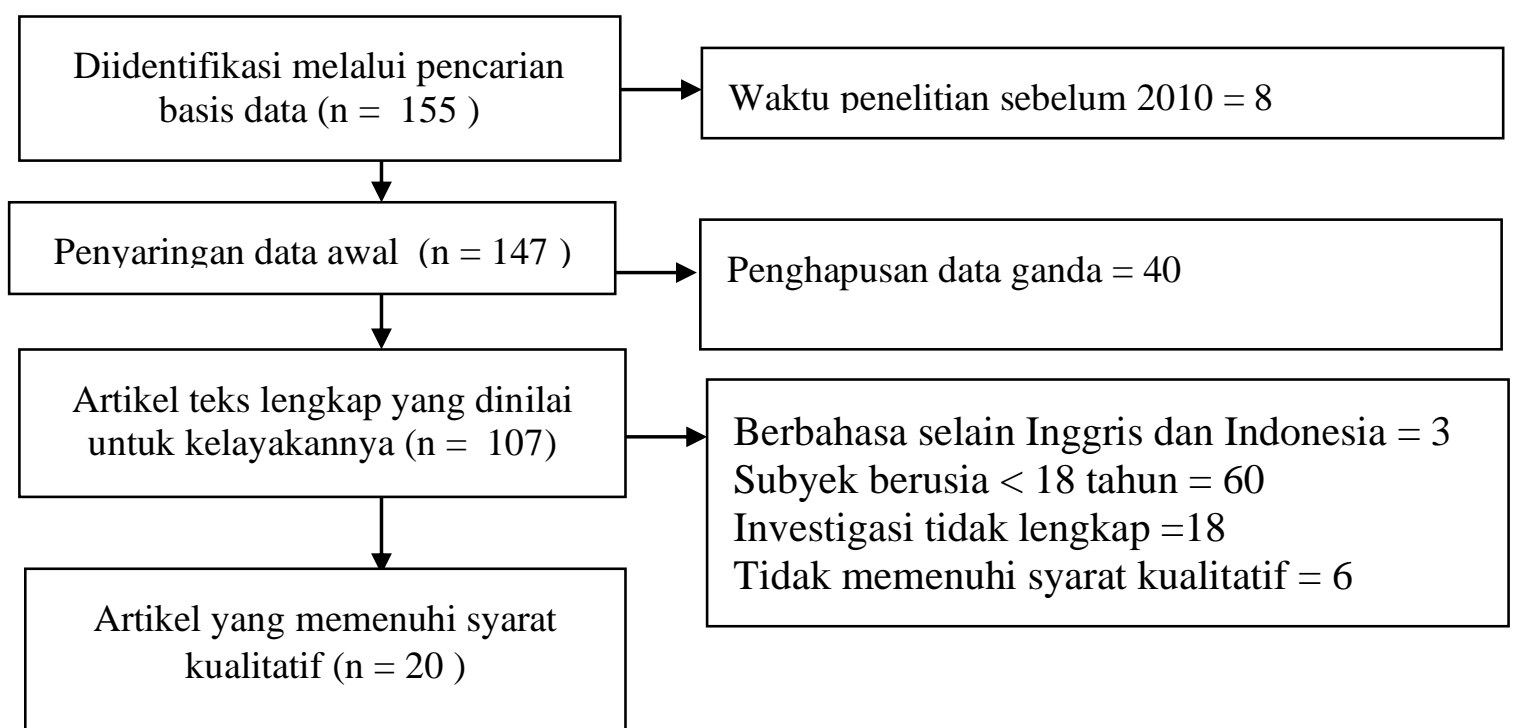

Gambar 1. Alur diagram PRISMA untuk seleksi artikel dalam tinjauan sitematis

\section{Tabel 1. Ringkasan hasil dari artikel yang memenuhi syarat kualitatif}

\begin{tabular}{|c|c|}
\hline $\begin{array}{l}\text { Penulis dan } \\
\text { Tahun }\end{array}$ & $\begin{array}{l}\text { Jenis Prehabilitasi pada kelompok } \\
\text { intervensi }\end{array}$ \\
\hline $\begin{array}{l}\text { (Barberan- } \\
\text { Garcia et al., } \\
2018)\end{array}$ & $\begin{array}{ll}\text { 1. } & \text { Motivasi wawancara. } \\
\text { 2. Pelatihan ketahanan intensitas } \\
\text { tinggi. }\end{array}$ \\
\hline
\end{tabular}

\section{Dampak Prehabilitasi}

Prehabilitasi meningkatkan hasil klinis pascaoperasi pada pasien kandidat berisiko tinggi untuk operasi perut mayor elektif, yang dijelaskan oleh kelompok intervensi melalui : (1) peningkatkan kapasitas aerobik $\triangle$ DET 135 (218)\%; P <0,001), (2) mengurangi jumlah pasien dengan komplikasi pascaoperasi sebesar 51\% (risiko relatif 0,5; interval kepercayaan 95\%, 0,3-0,8; P $=0,001),(3)$ menurunkan tingkat komplikasi $[1,4(1,6)$ dan $0,5(1,0) \quad(\mathrm{P}=0,001)]$ dibandingkan dengan kelompok kontrol.

\begin{tabular}{|c|c|c|}
\hline $\begin{array}{l}\text { (Gstoettner et } \\
\text { al., 2011) }\end{array}$ & $\begin{array}{l}\text { Pemanasan, peregangan, } \\
\text { keseimbangan dan penguatan, } \\
\text { instruksi olahraga harian. Selama } \\
45 \text { menit per minggu. }\end{array}$ & $\begin{array}{l}\text { Tidak ada peningkatan yang signifikan secara statistik } \\
\text { dalam fungsi yang diukur dengan kecepatan berjalan } \\
\text { pada pasien pascaoperasi lutut total arthoplasty POM1 } \\
\text { (prehab: mean }=56,8, \mathrm{SD}=17,7 \text {, perawatan biasa: } \\
\text { mean }=51,8, \mathrm{SD}=9,9, \mathrm{p}=4 \text { ) }\end{array}$ \\
\hline $\begin{array}{l}\text { (Huang, Chen } \\
\text { and } \\
2012)\end{array}$ & $\begin{array}{l}\text { Pengangkatan kaki lurus, } \\
\text { pengaturan lutut, pemompaan } \\
\text { pergelangan kaki, dan penguatan } \\
\text { olahraga. } 40 \text { menit setiap hari } 210 \\
\text { menit per minggu. }\end{array}$ & $\begin{array}{l}\text { Skor nyeri serupa atau sama pada kedua kelompok } 1 \\
\text { bulan setelah operasi pasca lutut total arthoplasty. }\end{array}$ \\
\hline $\begin{array}{l}\text { (Hoogeboom et } \\
\text { al., 2010) }\end{array}$ & $\begin{array}{l}\text { Pelatihan fungsional, Pemanasan, } \\
\text { latihan penguatan, dan } 20-30 \\
\text { menit latihan aerobik, } 120 \text { menit } \\
\text { per minggu. }\end{array}$ & $\begin{array}{l}\text { Tidak ada bukti bahwa kelompok prehab pulih lebih } \\
\text { cepat dari kelompok perawatan biasanya seperti yang } \\
\text { ditunjukkan oleh durasi hari untuk mencapai } \\
\text { kemandirian fungsional (prehab: median }=4, \mathrm{IQR}=3- \\
\text { 6, perawatan biasa: } \text { median }=4, \mathrm{IQR}=3-5, \mathrm{p}=9 \text { ). }\end{array}$ \\
\hline
\end{tabular}


(Oosting et al., Pelatihan aktivitas fungsional, dan 2012) fungsional berjalan. Sesi 30 menit per minggu; latihan mandiri $4 \times$ 120 menit per minggu.
Prehab tidak menghasilkan manfaat dalam fungsi obyektif pada pasien elective total hip arthroplasty yang diukur dengan mobilitas fungsional (TUG: prehab: mean $=13,4$ detik, $\mathrm{SD}=5,5$, perawatan biasa: mean $=13,8$ detik,

$\mathrm{SD}=11,1$, perbedaan rata-rata yang disesuaikan = 0,3, 95\% CI [- 2,7, 2,0]; dan kapasitas berjalan (6MWT: prehab: mean $=282 \mathrm{~m}, \mathrm{SD}=84$, rerata perawatan biasa $=339 \mathrm{~m}, \mathrm{SD}=69,95 \%$ CI $[-39,58])$. Ini sama untuk aktivitas fungsi fisik, kualitas hidup, dan nyeri.

(Nielsen et al., Latihan kardiovaskular 30 menit Prehab tidak menguntungkan secara obyektif pada 2010) per hari, 210 menit per minggu. peningkatan fungsi, kualitas hidup, dan nyeri pasien

\begin{tabular}{ll}
$\begin{array}{l}\text { Penulis dan } \\
\text { Tahun }\end{array}$ & $\begin{array}{l}\text { Jenis Prehabilitasi pada kelompok } \\
\text { intervensi }\end{array}$ \\
\hline $\begin{array}{ll}\text { (Carli et al., } \\
\text { 2010) }\end{array}$ & $\begin{array}{l}\text { Bersepeda, dan latihan beban 3,5 } \\
\text { jam per minggu. }\end{array}$ \\
\hline
\end{tabular}
yang telah menjalani operasi spinal (tulang belakang). Dampak Prehabilitasi

Kelompok prehab ditemukan lebih aktif secara fisik daripada kelompok perawatan biasa pada pasien operasi colorectal.

(De Toledo Peregangan, rotasi batang tubuh, Prehab tidak memberikan perbedaan signifikan pada Piza Soares et pernapasan dalam, al., 2013) pelatihan otot pernapasan, aktif kemampuan pasien untuk melakukan aktivitas seharihari 1 bulan setelah operasi abdominal. atas, latihan ekstremitas bawah, berjalan, dan relaksasi.

Sesi $2 \times 50$ menit per minggu.

(Barakat et al., Kelompok intervensi terdaftar 2014) dalam program. Parameter CPET treadmill sebelum dan sesudah operasi. Latihan diawasi selama enam minggu.

(Tew et al., Pelatihan high-intensity interval

2017) training (HIT) diberikan dalam tiga sesi latihan per minggu selama 4 minggu.

(Jensen et al., Latihan kekuatan dan ketahanan

2015) praoperasi dan mobilisasi pascaoperasi progresif. Program ini dimulai 2 minggu sebelum operasi.

(Howard et al., Michigan Surgical and Health 2019) Optimization Program (MSHOP) adalah program prehabilitasi formal yang melibatkan 4 aktivitas sebelum operasi: aktivitas fisik, rehabilitasi paru, optimalisasi nutrisi, dan pengurangan stres.

(Abdelaal et Latihan pernapasan umum selama al., 2017) 2 minggu dan dua sesi terapi pernapasan fisik dan khusus per minggu (masing-masing 40

Penelitian menunjukkan bahwa kebugaran aerobik kardiopulmoner meningkat setelah periode latihan yang diawasi pada pasien yang dijadwalkan untuk perbaikan abdominal aortic aneurys (AAA).

Meskipun intensitas latihan umumnya lebih rendah dari yang diharapkan, temuan mendukung kelayakan dan penerimaan HIT pre operasi.

Tidak ada penurunan masa rawat inap karena program rehabilitasi praoperasi dan pascaoperasi, meskipun demikian mobilisasi meningkat.

Pasien yang menjalani prehabilitasi sebelum kolektomi menunjukkan efek fisiologis positif dan komplikasi yang lebih sedikit. Penghematan rata-rata sebesar \$ 21.946 per pasien mewakili penggantian biaya yang signifikan untuk program prarehabilitasi.

Terapi fisik dan pernafasan sebelum operasi meningkatkan fungsi paru dan menurunkan kejadian komplikasi paru pascaoperasi pada pasien obesitas yang menjalani operasi laparoskopi perut bagian atas. 


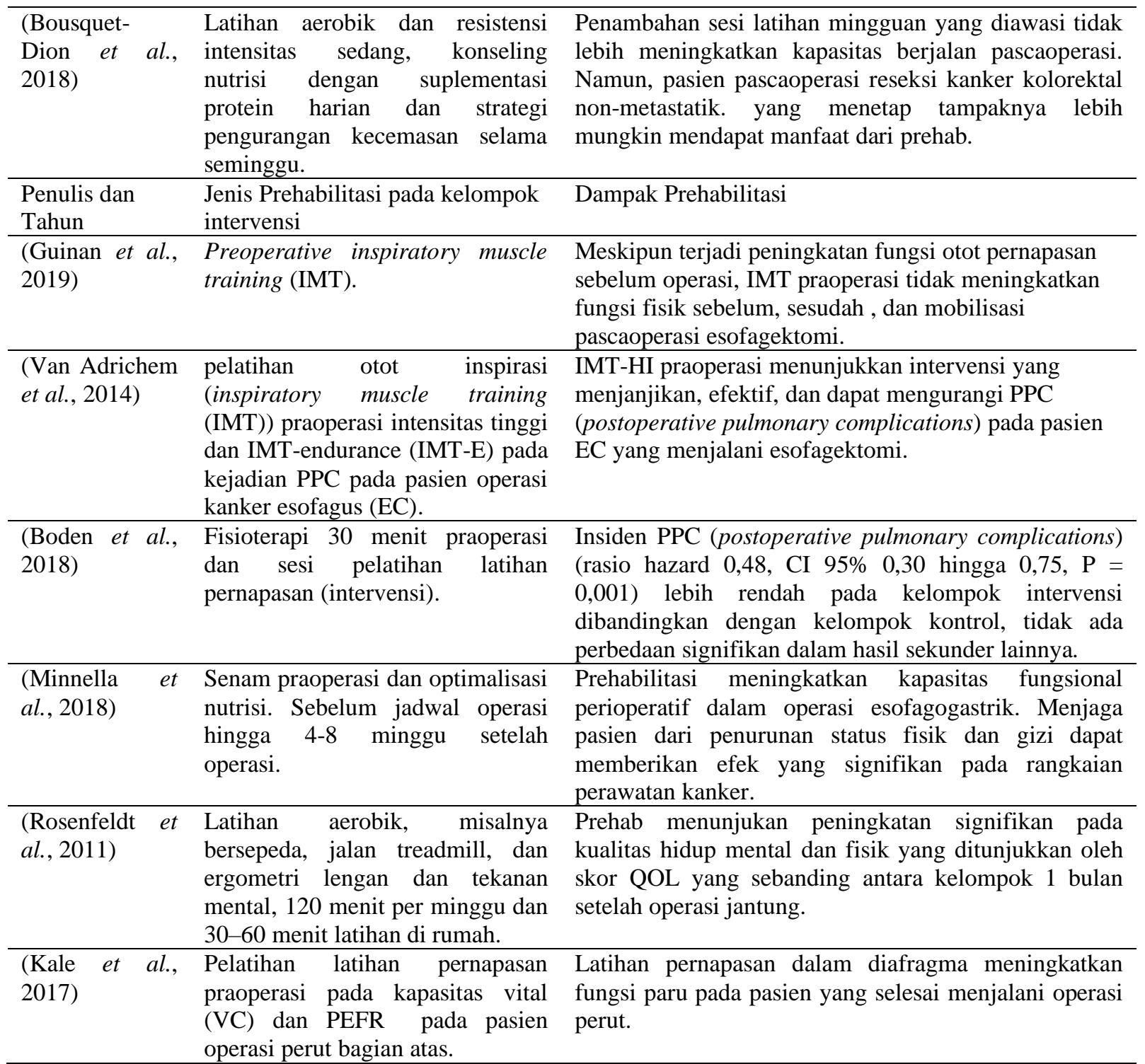

Berdasarkan penelitian yang telah terpublikasikan sebanyak 11 artikel (Carli et al., 2010; Rosenfeldt et al., 2011; Barakat et al., 2014; Van Adrichem et al., 2014; Abdelaal et al., 2017; Kale et al., 2017; Tew et al., 2017; Barberan-Garcia et al., 2018; Boden et al., 2018; Minnella et al., 2018; Howard et al., 2019) menyatakan bahwa prehabilitasi dapat memberikan efek yang positif terhadap pasien pascaoperasi, yang dibuktikan dengan berbagai indikator diantaranya: penurunan risiko komplikasi, peningkatan kapasistas organ vital, serta waktu pemulihan yang lebih cepat.

Namun, masih terdapat artikel yang melaporkan bahwa pasien pascaoperasi yang menerima prehabilitasi tidak menunjukan perbedaan signifikan dengan pasien tanpa prehabilitasi (Hoogeboom et al., 2010; Nielsen et al., 2010; Gstoettner et al., 2011; Huang, Chen and Chou, 2012; Oosting et al., 2012; De 
Toledo Piza Soares et al., 2013; Jensen et al., 2015; Bousquet-Dion et al., 2018; Guinan et al., 2019).

\section{Tabel 2. Tabel resiko bias}

\begin{tabular}{|c|c|c|c|c|c|}
\hline \multirow[t]{2}{*}{ Trial } & \multirow{2}{*}{$\begin{array}{l}\text { Lost to } \\
\text { follow up }\end{array}$} & \multicolumn{3}{|c|}{ Pembutaan (Blinding) } & \multirow{2}{*}{$\begin{array}{l}\text { Rasio } \\
\text { pembagian } \\
\text { kelompok }\end{array}$} \\
\hline & & Pasien & Terapis & $\begin{array}{l}\text { Pengumpul } \\
\text { data }\end{array}$ & \\
\hline (Barberan-Garcia) & Ada & Ya & Tidak & Tidak & $63: 62$ \\
\hline (Gstoettner et al) & Ada & Tidak & Tidak & $\mathrm{Ya}$ & $18: 20$ \\
\hline (Huang, et al) & Tidak ada & - & - & - & 126:117 \\
\hline (Oosting et al) & Ada & Ya & Tidak & Tidak & $15: 15$ \\
\hline (Hoogeboom et al) & - & Ya & Tidak & Tidak & 10:11 \\
\hline (Nielsen et $a l$ ) & - & $\mathrm{Ya}$ & Tidak & Tidak & $28: 32$ \\
\hline (De T Soares et al) & - & Tidak & Tidak & Tidak & $17: 16$ \\
\hline (Jensen et al) & Ada & Tidak & Tidak & Tidak & 50:57 \\
\hline (Bousquet-Dion) & Ada & $\mathrm{Ya}$ & Tidak & Tidak & $41: 39$ \\
\hline (Guinan et al) & Ada & Ya & Tidak & Tidak & $35: 37$ \\
\hline (Carli et al) & Ada & - & - & - & $58: 54$ \\
\hline (Barakat et al) & Tidak & - & - & - & 10:10 \\
\hline (Tew et al) & Ada & Ya & Tidak & Ya & $27: 26$ \\
\hline (Howard et al) & Ada & Ya & Tidak & Ya & $40: 40: 76$ \\
\hline (Abdelaal et al) & Tidak & - & - & - & $26: 24$ \\
\hline (Van Adrichem et al) & Ada & Tidak & Ya & Tidak & $23: 22$ \\
\hline (Boden et al) & Ada & Ya & Tidak & $\mathrm{Ya}$ & 219:222 \\
\hline (Minnella et al) & Ada & Tidak & Ya & Tidak & $34: 34$ \\
\hline (Rosenfeldt et al) & Ada & - & - & - & $60: 57$ \\
\hline (Kale et al., 2017) & - & - & - & - & $30: 30$ \\
\hline
\end{tabular}

Keterangan : Tidak dijelaskan di dalam artikel (-)

Berdasarkan tabel diatas beberapa potensi bias terjadi pada proses pembutaan (blinding), banyak studi yang hanya menggunakan single-blind, tidak membutakan tim pengumpul atau pengukur data bahkan melakukan RCT tanpa blinding. Selain itu, hampir seluruh studi melaporkan adanya lost to follow-up, namun hampir seluruh studi menggunakan rasio proporsional untuk masingmasing kelompok yakni 1:1.

Program rehabilitasi telah diperkenalkan untuk mengoptimalkan fungsi dan pemulihan fisik serta psikologis pasien sebelum menjalani perawatan operasi elektif mayor. Tinjauan sistematis menunjukan berbagai hasil yang menyatakan terdapat perbedaan signifikan bahkan yang tidak menunjukan perbedaan. Penulis menggunakan artikel RCT untuk mengurangi heterogenitas, meningkatkan sensitivitas, dan analisis hasil.

Mayoritas penelitian terbaru menunjukan hasil signifikan pada pasien yang menjalani operasi perut mayor, namun demikian penulis merasa masih kurangnya standardisasi akan jenis dan tahapan prehabilitasi. Latihan fisik dan latihan pernapasan paling sering digunakan dalam studi yang diidentifikasi dalam ulasan 
ini. Sehingga studi yang mengulas dan menerapkan standar prehabilitasi masih sangat dibutuhkan.

Latihan fisik tetap menjadi bentuk yang paling mudah karena tidak harus direhabilitasi oleh dokter spesialis dan dapat dilakukan kapan saja. Penggunaannya bergantung pada kebutuhan pasien, sebaliknya latihan pernapasan membutuhkan spesialis dan masukan dari fisioterapis untuk memastikan pasien mendapat informasi tentang teknik yang benar (Cabilan, Hines and Munday, 2016). Prehabilitasi berupa latihan fisik yang sesuai kebutuhan pasien dan latihan pernafasan sesuai petunjuk dokter dan terapis bisa diterapkan pada pasien-pasien yang akan menjalani operasi selektif mayor.

Pada pasien yang menjalani operasi jantung, perut, dan tulang belakang. Bukti yang ada belum cukup untuk membuat kesimpulan tentang manfaat signifikan prehab, meskipun demikian latihan ringan masih dapat diberikan dan hasilnya dianalisis menurut volume latihan yang diterima per minggu (Cabilan, Hines, \& Munday, 2015).

Penulis berpendapat sebagai besar program rehabilitasi yang sukses, tidak hanya berfokus pada fisik melainkan psikologis. Prehabilitasi psikologis termasuk nasihat atau pendidikan tentang strategi untuk mengatasi stres akibat menjalani operasi besar. Beberapa studi dalam bedah kardiotoraks dan perut telah memasukkan pendekatan pengurangan kecemasan melalui latihan pernapasan dengan psikolog terlatih sebagai bagian dari program rehabilitasi (Gillis et al.,2014).

Pemberian layanan prehabilitasi psikologis berupa konseling dan pemantauan kondisi kejiwaan dapat dimaksimalkan dengan pemanfaatan tekhnologi telemedicine. Telemedicine dapat memberikan dampak positif dalam penghematan biaya kesehatan, peningkatan kepuasan serta perluasan layanan tanpa harus memindahkan sumber daya (Atmojo et al.,2020).

\section{SIMPULAN DAN SARAN}

\section{Simpulan}

Secara keseluruhan dapat dijelaskan bahwa prehabilitasi cenderung memberi efek positif pada pasien pascaoperasi, meskipun tidak ada penelitian yang mengevaluasi hasil jangka panjang. Tinjauan sistematis ini masih dibatasi oleh heterogenitas studi berkenaan dengan jenis pembedahan, cara rehabilitasi, dan berbagai bias yang sudah dilaporkan sebelumnya sehingga masih ada peluang untuk penelitian terkait standardisasi atau konsensus lebih lanjut terkait prehabilitasi untuk menetapkan pedoman.

\section{Saran}

Prehabilitasi dapat diberikan kepada pasien yang akan menjalani operasi selektf mayor atau minor, meskipun masih terdapat penelitian yang tidak melaporkan perbedaan signifikan, namun belum ada penelitian terpublikasi yang memberikan laporan negatif terkait prehabilitasi. Upaya prehabilitasi fisik harus 
juga diimbangi dengan pemberian upaya penanganan masalah psikologis agar memberikan hasil maksimal.

\section{DAFTAR PUSTAKA}

Abdelaal, G. A. et al. (2017) 'Effect of preoperative physical and respiratory therapy on postoperative pulmonary functions and complications after laparoscopic upper abdominal surgery in obese patients', Egyptian Journal of Chest Diseases and Tuberculosis. doi: 10.1016/j.ejcdt.2017.10.012.

Atmojo JT, Sudaryanto WT, Widiyanto A, Ernawati, Arradini D. (2020). Telemedicine, Cost Effectiveness, and Patients Satisfaction: A Systematic Review. Journal of Health Policy and

Management (2020), 5(2): 103-107. doi.org/10.26911/thejhpm.2020.05.02.02.

Van Adrichem, E. J. et al. (2014) 'Comparison of two preoperative inspiratory muscle training programs to prevent pulmonary complications in patients undergoing esophagectomy: A randomized controlled pilot study', Annals of Surgical Oncology. doi: 10.1245/s10434-014-3612-y.

Barakat, H. M. et al. (2014) 'Supervised exercise program improves aerobic fitness in patients awaiting abdominal aortic aneurysm repair', in Annals of Vascular Surgery. doi: 10.1016/j.avsg.2013.09.001.

Barberan-Garcia, A. et al. (2018) 'Personalised Prehabilitation in High-risk Patients Undergoing Elective Major Abdominal Surgery: A Randomized Blinded Controlled Trial', Annals of Surgery. doi: 10.1097/SLA.0000000000002293.

Boden, I. et al. (2018) 'Preoperative physiotherapy for the prevention of respiratory complications after upper abdominal surgery: Pragmatic, double blinded, multicentre randomised controlled trial', The BMJ. doi: 10.1136/bmj.j5916.

Boshier, P. R. et al. (2018) 'Assessment of body composition and sarcopenia in patients with esophageal cancer: A systematic review and meta-analysis', Diseases of the Esophagus. doi: 10.1093/dote/doy047.

Bousquet-Dion, G. et al. (2018) 'Evaluation of supervised multimodal prehabilitation programme in cancer patients undergoing colorectal resection: a randomized control trial', Acta Oncologica. doi: 10.1080/0284186X.2017.1423180.

Cabilan, C. J., Hines, S. and Munday, J. (2016) 'The impact of prehabilitation on postoperative functional status, healthcare utilization, pain, and quality of life a systematic review', Orthopaedic Nursing, 35(4), pp. 224-237. doi: 10.1097/NOR.0000000000000264.

Carli, F. et al. (2010) 'Randomized clinical trial of prehabilitation in colorectal surgery', British Journal of Surgery. doi: 10.1002/bjs.7102.

Gstoettner, M. et al. (2011) 'Preoperative proprioceptive training in patients with total knee arthroplasty', Knee. doi: 10.1016/j.knee.2010.05.012. 
Guinan, E. M. et al. (2019) 'Effect of preoperative inspiratory muscle training on physical functioning following esophagectomy', Diseases of the Esophagus. doi: 10.1093/dote/doy091.

Gillis C, Li C, Lee L, et al. Prehabilitation versus rehabilitation: a randomized control trial in patients undergoing colorectal resection for cancer. Anesthesiology. 2014;121:937e947.

Hoogeboom, T. J. et al. (2010) 'Preoperative therapeutic exercise in frail elderly scheduled for total hip replacement: A randomized pilot trial', Clinical Rehabilitation. doi: 10.1177/0269215510371427.

Howard, R. et al. (2019) 'Taking Control of Your Surgery: Impact of a Prehabilitation Program on Major Abdominal Surgery', Journal of the American College of Surgeons. doi: 10.1016/j.jamcollsurg.2018.09.018.

Huang, S. W., Chen, P. H. and Chou, Y. H. (2012) 'Effects of a preoperative simplified home rehabilitation education program on length of stay of total knee arthroplasty patients', Orthopaedics and Traumatology: Surgery and Research. doi: 10.1016/j.otsr.2011.12.004.

Jensen, B. T. et al. (2015) 'Efficacy of a multiprofessional rehabilitation programme in radical cystectomy pathways: A prospective randomized controlled trial', Scandinavian Journal of Urology. doi: $10.3109 / 21681805.2014 .967810$.

Kale, P. M. et al. (2017) 'The effectiveness of pre-operative deep breathing exercise on post-operative patients of abdominal surgery', Asian Journal of Pharmaceutical and Clinical Research. doi: 10.22159/ajpcr.2017.v10i2.14912.

Kamarajah, S. K. et al. (2020) 'Critical appraisal on the impact of preoperative rehabilitation and outcomes after major abdominal and cardiothoracic surgery: A systematic review and meta-analysis', Surgery (United States). Elsevier Inc., 167(3), pp. 540-549. doi: 10.1016/j.surg.2019.07.032.

Kamarajah, S. K., Bundred, J. and Tan, B. H. L. (2019) 'Body composition assessment and sarcopenia in patients with gastric cancer: a systematic review and meta-analysis', Gastric Cancer. doi: 10.1007/s10120-0180882-2.

Liberati, A. et al. (2009) 'The PRISMA statement for reporting systematic reviews and meta-analyses of studies that evaluate healthcare interventions: explanation and elaboration', Bmj, 339(jul21 1), pp. b2700b2700. doi: 10.1136/bmj.b2700.

Mayo, N. E. et al. (2011) 'Impact of preoperative change in physical function on postoperative recovery: Argument supporting prehabilitation for colorectal surgery', Surgery. doi: 10.1016/j.surg.2011.07.045.

Minnella, E. M. et al. (2018) 'Effect of Exercise and Nutrition Prehabilitation on Functional Capacity in Esophagogastric Cancer Surgery: A Randomized Clinical Trial', JAMA Surgery. doi: 10.1001/jamasurg.2018.1645. 
Nielsen, P. R. et al. (2010) 'Prehabilitation and early rehabilitation after spinal surgery: Randomized clinical trial', Clinical Rehabilitation. doi: $10.1177 / 0269215509347432$.

Older, P. O. and Levett, D. Z. H. (2017) 'Cardiopulmonary exercise testing and surgery', in Annals of the American Thoracic Society. doi: 10.1513/AnnalsATS.201610-780FR.

Oosting, E. et al. (2012) 'Preoperative home-based physical therapy versus usual care to improve functional health of frail older adults scheduled for elective total hip arthroplasty: A pilot randomized controlled trial', Archives of Physical Medicine and Rehabilitation. doi: 10.1016/j.apmr.2011.11.006.

Rose, J. et al. (2015) 'Estimated need for surgery worldwide based on prevalence of diseases: A modelling strategy for the WHO Global Health Estimate', The Lancet Global Health. doi: 10.1016/S2214-109X(15)70087-2.

Rosenfeldt, F. et al. (2011) 'Physical conditioning and mental stress reduction - a randomised trial in patients undergoing cardiac surgery', $B M C$ Complementary and Alternative Medicine. doi: 10.1186/1472-6882-11-20.

Tew, G. A. et al. (2017) 'Randomized feasibility trial of high-intensity interval training before elective abdominal aortic aneurysm repair', British Journal of Surgery. doi: 10.1002/bjs.10669.

De Toledo Piza Soares, S. M. et al. (2013) 'Pulmonary function and physical performance outcomes with preoperative physical therapy in upper abdominal surgery: A randomized controlled trial', Clinical Rehabilitation. doi: 10.1177/0269215512471063.

Valkenet, K. et al. (2011) 'The effects of preoperative exercise therapy on postoperative outcome: A systematic review', Clinical Rehabilitation. doi: 10.1177/0269215510380830.

Wittink, H., Engelbert, R. and Takken, T. (2011) 'The dangers of inactivity; exercise and inactivity physiology for the manual therapist', Manual Therapy. doi: 10.1016/j.math.2011.01.006. 